\title{
Why Do Entrepreneurs Refuse Venture Capital?
}

\author{
Annalisa Croce, Luca Grilli, Samuele Murtinu* \\ Politecnico di Milano \\ Department of Management, Economics and Industrial Engineering
}

*Corresponding author. Postal address: via R. Lambruschini, 4b - 20156, Milan, Italy. Email: samuele.murtinu@polimi.it. Ph.: +39 02 23992807. Fax: +39 0223992710.

Keywords: venture capital, high-tech entrepreneurship, human capital, family ownership

JEL codes: G24; L21; L25; L26; M13; M21

\begin{abstract}
Several papers in the venture capital (VC) literature have studied the decision criteria put in use by $\mathrm{VC}$ investors (VCs) in selecting promising young high-tech entrepreneurial ventures. To the best of our knowledge, there are no studies in the extant literature that study the determinants of VC refusal by entrepreneurs. This issue is extremely relevant because the current public policies favor the development of VC markets/VC supply. However, given that some entrepreneurial ventures refuse VC financial offers, a full understanding of the determinants of such refusal could allow to design more suited VC policies. In this study, we take the perspective of the entrepreneur and perform several analyses. First, we study the determinants of the likelihood to refuse VC through a probit model. Second, by means of a multinomial logit approach, we investigate the motivations behind the decision to refuse a $\mathrm{VC}$ offer. Third, by means of a random effects and switching regression model estimation, we estimate the impact of $\mathrm{VC}$ refusal on a firm's growth in sales value and total assets. Our work provides important implications for policymakers and entrepreneurs.
\end{abstract}




\section{Introduction}

Several papers in the finance and economics literature have studied the decision criteria put in use by Venture Capital investors (VCs) in selecting promising entrepreneurial firms (Hellmann and Puri, 2000). To a less extent, scholars have attempted to understand the driving forces that lead entrepreneurs to search for Venture Capital (VC) funding (Hellmann, 1998; Bertoni et al. 2015). At first glance, one might think that VC backing provides only advantages to entrepreneurs, such as financial resources, advice, and access to other investors, suppliers and clients. However, VC funding encompasses a venture's stake and this may also bring disadvantages, such as conflicts about corporate strategy, (Hellmann and Puri, 2000), appropriability hazards (Ueda, 2004), and excessive intrusion in a firm's management (Sapienza, 1992).

Thus, entrepreneurs can have several motivations to refuse VC funding (Forbes, 2013), especially if their venture appeals to other VCs. Broadly, such motivations embrace three different situations: i) a focal entrepreneur is not on the "VC market"; i.e. whether or not she is looking for external finance, in any case VC is not her best choice (i.e. "no need of VC"); ii) the focal entrepreneur refuses VC as she/he fears to lose ownership and control (i.e. "fear to lose control"); or iii) the financial transaction between the VC investor and the entrepreneur does not end up with a contract, because of undesirable offer terms and/or valuation price (i.e. "undesirable offer terms and valuation prices"). The aim of this study is first to understand which characteristics at venture level influence the probability that entrepreneurs refuse VC. Secondly, we analyze more in details which of these characteristics are more associated to the three different motivations aforementioned for explaining the VC refusal choice by entrepreneurs. Grounding on the extant literature, we identify three major firm-level possible drivers. First, the literature about VC selection criteria points to founders' human capital characteristics as an important selection criterion followed by VCs. For instance, Sapienza et al. (1996) find that entrepreneurs prefer VCs with a background similar to theirs. Although strategic and financial considerations play a big role in the target evaluation process, ' $[\mathrm{t}]$ here is no question that irrespective of the horse (product), horse race (market), or odds (financial criteria), it is the jockey (entrepreneur) who fundamentally determines whether the venture capitalist will place a bet at all' (MacMillan et al., 1985, p. 119). Second, firm size determines firm's outside finance options. As shown by Beck and Demirguc-Kunt (2006), larger have better access to external finance sources. Everything else being equal, firm size may positively impact the spectrum of available sources of finance for the venture, making less compelling for a firm to obtain VC financing. Even though there is empirical evidence on the relationship between VC and the size of portfolio companies (Puri and Zarutskie, 2012), we claim that firm size may also play a role on the likelihood to refuse VC, for the reasons sketched above. Third, one other 
important issue which may affect the whole negotiation process is how much the entrepreneur is (emotionally and economically) "bonded" to her venture. In this respect, ownership structure and firm control are important factors to be considered. Specifically, previous literature is almost unanimous in identifying family ownership as a key characteristic: family firm owners may be more averse to giving away control over the family business to outsiders, and this reluctance may affect their attitudes towards external investors such as VC institutions (Villalonga and Amit, 2009).

In this perspective, our study aims at shedding light on this issue by analyzing the role of these variables in the entrepreneurial decision to refuse $\mathrm{VC}$ financing and in the motivations provided to justify this choice. Moreover, we estimate the impact of this choice on a venture growth performance. Then by performing a sort of "sliding doors" analysis, we also aim at investigating whether or not alternative choices to those effectively made by entrepreneurs (i.e. accept or refuse of VC funding) would have brought the firm to higher growth performances. In a nutshell, we perform four types of econometric analyses. First, we study the determinants of the likelihood to refuse VC. Second, we investigate the motivations behind this decision. Third, we estimate the impact of VC refusal on firm's growth. Fourth, we answer the following questions: i) what would the growth of a company that refused VC have been had it not refuse VC?; ii) what would the growth of a VC-backed company have been had it refused VC?.

To the best of our knowledge, there are no other studies in the extant literature that study the determinants and the motivations of VC refusal by entrepreneurs and the effects of these choices on the growth trajectories of entrepreneurial ventures.

The sample used to test our research hypotheses is composed of 120 Italian high-tech entrepreneurial firms that received a VC financing offer from their foundation up to the year 2008. It is important to highlight that this sample is by definition unaffected by any possible problem related to the inclusion in the estimation procedures of firms that would have never figure as target for a VC investor: in fact, the sample is only made by ventures that did receive at least one VC offer during their life.

Our results may be summarized as follows. Family ownership positively impacts the choice to refuse VC; conversely, founders' technical work experience negatively impacts a venture's probability to refuse an offer. Second, when investigating the motivations behind the refusal decision, we find that size of the founding team is positively correlated with the fear to lose control. Moreover, firm familiness is negatively correlated with the probability to refuse an offer because of undesirable offer terms and valuation prices, while is more likely for family firms to refuse VC simply because they did not think to need it. Conversely, founders' economic education raises the probability to refuse VC because of undesirable offer terms and valuation prices, while it decreases 
the probability to refuse it because it was deemed unneeded. Finally, we find that VC refusal negatively impacts a firm growth performance in term of total assets and sales value. Moreover, VC-backed firms show a 53.5\% higher growth in total assets than what the same firms would have shown had they not received VC funding. Similarly, firms refusing VC show a decrease in total assets growth of 6.472 times and a decrease in sales growth of $33.4 \%$ than what the same firms would have shown had they received VC funding. Our work provides important implications for policy makers, and entrepreneurs. First, we highlight that VC is beneficial to entrepreneurial firms, but at the same time we document that there are rational reasons for (talented) entrepreneurs to refuse a VC's offer given their inherent characteristics and those of their firm. Policy makers may carve out an important role in this respect by designing consultancy schemes and/or financial mechanisms which aims at reducing the hurdles towards VC financing posed by these characteristics. Second, we highlight the importance for entrepreneurs of possessing the necessary skills and competences to properly evaluate the offers proposed by VCs.

The rest of the paper is organized as follows. Next section provides a literature review that aims at contextualizing our empirical enquiries. The subsequent sections are devoted to describe the dataset, the estimation methodologies we employ and the results of the analyses performed. Finally, a discussion of the main findings and their implications concludes the paper.

\section{Literature Review}

Many papers in the finance and economics literature have investigated the criteria put in use by VCs in selecting promising entrepreneurial firms (Fried and Hisrich, 1994; Hellmann and Puri, 2000; Baum and Silverman, 2004). Ever since the contribution of Tyebjee and Bruno (1984), several studies have showed that VCs look predominantly at technology and market opportunities of potential investees, management team capabilities, as well as the stage of business idea development. A limited number of contributions have studied the reasons that lead entrepreneurs to search for VC. From the point of view of entrepreneurs, the reader might think that VC endorsement provides mainly advantages. In fact, VCs make available to investees not only financial resources, but also coaching, advice, mentoring, and access to investment bankers and networks of suppliers, clients and customers. But VC financing is an equity investment. The fact that VC takes a venture's stake may also bring disadvantages from the entrepreneur's viewpoint. First, the strategic vision of VCs might diverge from that of the entrepreneurs. This possibly leads to conflicts between entrepreneurs and VCs that absorb entrepreneurs' time and energy to the detriment of firm performance (Hellmann, 1998). ${ }^{1}$ Second, appropriability hazards toward

\footnotetext{
${ }^{1}$ Sapienza et al. (1994) find that such conflict is greater in high-tech industries.
} 
entrepreneurial ventures' technology, and the related fear of expropriation might induce entrepreneurs with the most promising novel technologies to self-select out of the VC market (Ueda, 2004), and look elsewhere for other sources of external financing. Finally, while some VCs - e.g. government-managed VC funds (Cumming et al., 2014; Grilli and Murtinu, 2014a,2014b) take an 'hands-off' approach to venture oversight (Bottazzi et al., 2008), others are very active in monitoring entrepreneurs' behavior: many entrepreneurs see the managerial activism of VCs as an excessive intrusion in a firm's management (Sapienza, 1992).

The VC-investee relationship has been studied through the agency cost theory (Jensen and Meckling, 1976; Sahlman, 1990). The main idea is that VCs (principals) must structure the relationship to protect their investment from the potential moral hazards and opportunism of the entrepreneurs (agents). Bounded rationality of VCs and investees leads to information asymmetry (Amit et al., 1990, 1998): entrepreneurs might try to oversell the quality of their venture to secure better offer terms and valuation price. In the deal negotiation before the stock purchase agreement, VCs usually want to insert contractual clauses related to veto rights on entrepreneurs' decisions, power to replace the founders/CEOs and/or other key managers of investees, stock options, liquidation preferences, dilution protection clauses, and 'ratchets' (Hellmann, 1998). In the deal negotiation, the valuation price is the most crucial variable to assess the return of the focal investment exit (Sahlman, 1990): as shown by Hsu (2004), offers by highly reputable VCs are three times more likely to be accepted, and high reputable VCs benefit from a 10-14\% discount. In the subsequent deal structure, VCs fix the shareholder agreement covenants (Hellmann, 1998), such as the amount and timing of investment stages, the rights to access information on the venture behavior (e.g., budget plans, internal reports), restrictions on asset disposal, and buy-back provisions. It is worth noting that agency theory is more suited to study the VC-investee relationship before the investment. In fact, uncertainty and information asymmetries are at their highest level during the due diligence process, and not after the deal closing.

Thus, entrepreneurs can have several motivations to refuse VC, especially if their venture appeals to other VCs, the entrepreneur has more bargaining power and thus can better negotiate the offer terms. To investigate the main economic variables that influence such motivations, and thus the entrepreneurial behavior, we analyze the three most important variables highlighted by the extant literature.

First, the literature on VC highlights that founders' human capital is an important selection criterion of VCs' target choice (Muzyka et al., 1996). Sapienza et al. (1996) find that entrepreneurs prefer VCs with a similar background to theirs. Baum and Silverman (2004, p. 417) claim that: "[i]n the popular business press, VCs commonly report that "nothing is more important than people". 
Zacharakis and Meyer (2000) find that past experience of top management teams is a common selection driver of VCs. Burton et al. (2001) show that the likelihood to obtain external capital is directly correlated with the reputation of former employers of founding team members. Some few studies focus on the investigation of the VC-investee relationship after the venture has been funded (e.g., Cable and Shane, 1997). But generally, these contributions do not take into account that characteristics of entrepreneurs' human capital might also explain the choice of the focal entrepreneur to refuse VC.

Second, the finance literature highlights how firm size is correlated with growth obstacles and access to external finance (Beck and Demirguc-Kunt, 2006). More specifically, smaller firms are more likely to face deficiencies in the access to external finance that may hinder their growing path to their optimal size (Berger and Udell, 1998). Beck et al. (2006) show that small firms demand and obtain smaller loans, because of higher transaction costs and higher information asymmetries. This is due to their higher opacity (i.e., less disclosure requirements than larger and listed firms) and their lower level of tangible assets to pledge as collateral to the external financiers. Beck et al. (2005) proved that these higher obstacles to obtain external finance have a negative backlash on the small firms' growth performance. Even though there is empirical evidence on the relationship between VC and the size of portfolio companies (Puri and Zarutskie, 2012), there are no studies that investigate the relationship between firm size and the likelihood to refuse VC. In this study, we claim that the larger is the firm size, the higher could be the likelihood that an entrepreneur refuses VC. First, large firms should have relatively more external (e.g. banks) and internal (e.g. cash sources to finance their operations than small firms, making VC less appealing in comparative terms for them. Secondly, following established argumentations in the stream of innovation studies, e.g. Teece (1986) and Arora and Ceccagnoli (2006), firm size proxies for marketing and manufacturing assets, and thus larger firms are less in need of those complementary assets provided by VCs in the form of links to suppliers, customers, and clients which are necessary to produce and commercialize products and services.

Third, ownership structure and firm control is another important factor affecting the VC-investee negotiation process. In this respect, family ownership appears as a prominent characteristic to duly take into account. The extant literature suggests that family firm owners may be more averse to giving away control over the family business to outsiders, and this may affect their attitudes towards external investors such as VC institutions. In an explorative study of cross-sectional data on UK family firms, Poutziouris (2001) indicates that financial development in family firms is governed by the 'keep it in the family' tradition. Family firms are systematically more dependent on internally generated funds (i.e., retained profits) for their survival and development than non-family ones. In 
addition, they are not enthusiastic about widening the equity base at the cost of handing over family business control. Tappeiner et al. (2012) perform case studies of 21 large family firms in Germany in which owners employ private equity finance. They find that family firm owners balance the financial and non-financial resources provided by private equity investors with the need to hand over control rights to them.

\section{Data}

The sample used to test our research hypotheses is drawn from the RITA (Research on Entrepreneurship in Advanced Technologies) dataset, developed at Politecnico di Milano.

Firms in RITA dataset were established from 1980 to 2008, were independent at foundation date and remained so up to 1/1/2008 (i.e., they were not controlled by another business organisation although other organisations may have held minority shareholdings). All sample firms are privately held. They operated in the following high-tech industries in manufacturing and services: computers, electronic components, telecommunication equipment, optical, medical and electronic instruments, biotechnology, pharmaceuticals, advanced materials, avionics, robotics and process automation equipment, multimedia content, software, Internet services, and telecommunication services.

The RITA dataset provides information on 1,974 Italian entrepreneurial firms that comply with the above mentioned criteria relating to age, ownership and industry of operations. ${ }^{2}$ The data included in the RITA dataset originate from two sources. The first source is a series of surveys administrated in the first halves of 2000, 2002, 2004 and 2008 sent to the firms included in the RITA population. The second data source includes secondary sources from which we obtained financial and accounting data (i.e., the AIDA and CERVED commercial databases), which are available from 1994 to 2009.

Data collected through these surveys include the information on whether firms received a VC offer at their foundation or after. In particular, firms were asked to indicate if they received a VC offer during their lives, if they refused it or not and, in case of refusal, firms were asked to indicate the motivation of refusal. In case of acceptance of a VC offer, data on investments were provided (e.g. year of VC investment, type of VC investor, syndication, exit type). Out of 1,974 RITA firms, only

\footnotetext{
${ }^{2}$ For the construction of the RITA population of firms a number of sources were used. These included lists provided by national industry associations, on-line and off-line commercial firm directories, and lists of participants in industry trades and expositions. Information provided by the national financial press, specialized magazines, other industry studies, and regional Chambers of Commerce was also considered. Unfortunately, data provided by the official national statistics do not allow to obtain a reliable description of the universe of Italian entrepreneurial firms. In the absence of official statistics on Italian high-tech entrepreneurial firms, the RITA dataset is the most detailed and comprehensive source of data on this type of firms.
} 
120 firms received a VC offer. ${ }^{3}$ These are the only firms included in our analysis in order to ascertain the determinants and the impact of VC refusal. Out of these 120 high-tech entrepreneurial firms, 40 refused and 80 accepted the VC offer.

The RITA dataset has several strengths. First, data on sample firms are very informative and allow us to build a rich set of variables that can be used in the econometric estimation. Second, it provides information on the whole components of the founding team, representing a strong advantage compared with recent studies related to entrepreneurship dynamics that were forced to rely only on data on the principal founder (e.g., Hmieleski Corbett and Baron 2013, Rauch and Rijsdijk 2013). Third, the RITA dataset provides an ideal testbed for identifying those ventures that could receive an offer by a VC since the dataset does not include any lifestyle firms and firms that are created purely for tax-saving objectives because of the procedure that was used to build the RITA population of firms. ${ }^{4}$

The distribution of sample firms across industries, geographic areas and foundation dates is illustrated in Table 1. More than one-half of sample firms operate in software and Internet industries (53.33\% of total sample). Firms accepting VC operate more in Software \& Internet (57.50\%) than in the sample of $\mathrm{VC}$ refusing firms (45\%) that, conversely, are more present in manufacturing ICT industries (35\%). Moreover, firms accepting VC are more located in the north-western part of Italy $(45.00 \%)$, while the $42.5 \%$ of VC refusing firms are located in the north-eastern part of Italy. Differences in both industry and geographical area are statistically significant at $10 \%\left(\chi^{2}(3)=7.254\right.$ and $\chi^{2}(3)=6.789$, respectively for industry and geographical area). The $\chi^{2}$ tests show that there is no statistically significant difference between the distribution of the two samples firms across foundation period $\left(\chi^{2}(5)=0.884\right)$.

[Table 1 about here]

\section{Results}

\section{Determinants of VC refusal}

In order to compare firms refusing VC and VC-backed firms we first look at the descriptive statistics provided in Table 2.

We compare the characteristics considered in this study as possible determinants of a VC refusal by the entrepreneurial venture. First, as proxy of founders' human capital we include the economic education of founders (measured by a dummy indicating that at least one of the founders has gained

\footnotetext{
${ }^{3}$ These 120 firms are not statistically different from the sample of 1,974 firms included in RITA from which our sample is extracted in terms of industry, geographical location and foundation year.

${ }^{4}$ In Italy, most individuals who are defined as self-employed by official statistics (i.e., 'independent employees') are in fact salaried workers with atypical employment contracts. This makes the official number of high-tech entrepreneurial firms in Italy enormously inflated.
} 
a bachelor degree in an economic subjects) and their technical education (measured by a dummy indicating that at least one of the founders has obtained a bachelor degree in a technical subject). Then, managerial experience is a dummy variable indicating whether at least one of the founders has matured managerial experience in a previous occupation.

Second, as proxy of firm size we consider the size of the founding team, i.e. " $n$. founders" (measured by the number of founders in logarithm) and the size of firm at foundation, i.e. " $n$. employees" (measured by the number of employees in logarithm at foundation). Third, we control for firms familiness by including a dummy variable dummy taking value 1 if the focal firm is a family firm and 0 otherwise. Finally, a dummy variable born before 2000, taking value 1 for firms that were found and received a VC offer before 2000 is included as to control for the Dot-com bubble's boom and burst.

[Table 2 about here]

Results show no significant differences among VC-backed firms and firms refusing VC in terms of number of founders, education (in both economic and technical terms) and managerial experience. Similarly, no differences are found in terms of number of employees. We do not find statistical differences between the two groups of firms in terms of distributions of firm across the Internet bubble. The only statistical difference we found is relative to the presence of family firms in the two groups of firms: a significant higher number of family firms is present in the group of firms refusing VC.

In Table 3 we compare these variables across the different motivations provided by firms for refusing VC. We classify firms according to three categories: the first is composed by firms refusing VC because they affirmed not to have any financial need that a VC could have helped to solve (i.e. "no need of VC"). The second category is composed by firms indicating the necessity to preserve the ownership and control of their firm as principal motivation for VC refusal (i.e. "fear to lose control"). Finally, the third category is composed by firm refusing VC because they were not satisfied by the conditions posed by VC to sign the contract (i.e." Undesirable offer terms and valuation prices"). Results indicate that firms whose founding teams have higher economic education are more likely to refuse VC because of " undesirable offer terms and valuation prices", while firms whose founders possess a higher technical education level and higher managerial experience are more likely to refuse because of the "fear to lose control". Larger firms, in terms of both founders and employees, seems to resort more to the motivation of "fear to lose control" in order to explain their VC refusal. Firms born before 2000 are more likely to refuse VC because of 
"undesirable offer terms and valuation prices". Finally, family firms seem to indicate the "fear to lose control" as the principal motivation of their decision to refuse VC.

[Table 3 about here]

To validate this first set of evidence provided by the descriptive statistics we then resort to a multivariate analysis trough a probit model in order to analyse which characteristics, ceteris paribus, are more likely to influence the probability to refuse VC. The dependent variable takes value 1 if a firm refused a VC offer. Otherwise, for VC-backed firms, the dependent variable takes value 0 . In model I, the independent variables include the size of founder's team " $n$. founders" and the size of firm at foundation " $n$. employees", the dummy variable born before 2000 and the dummy family. Industry and geographical location dummies are included as to control for sectoral and geographical differences.

In model II, we add to the aforementioned independent variables, proxies of the human capital of founders, in terms of both economic and technical education, while, in model III, we add the variable capturing managerial experience. Finally, in model IV both founders' economic education, technical education and managerial experience are included in the model. Results are reported in Table 4.

[Table 4 about here]

Results partially confirm what we find in the descriptive statistics: family firms are significantly more likely to refuse VC. Moreover, this multivariate analysis indicates, everything else being equal, the significance of founders' economic education in influencing the decision to refuse VC: in particular, the higher the economic education of founders the lower is the probability to refuse VC.We then proceed to a multivariate analysis in order to analyse the determinants of the different motivations firms provide for refusing VC by resorting to a multinomial logit model. The dependent variable is categorical and assumes three different values according to the different type of motivation of VC refusal: "no need of VC", "fear to lose control" and "undesirable offer terms and valuation prices". The baseline outcome is represented by the situation of no VC refusal, i.e. the dependent variable is always equal to zero for all VC-backed companies. For firms refusing VC, the dependent variable equals: i) one if a firm refused VC because of "no need of VC"; ii) two if the refusal is motivated by "fear to lose control"; iii) three if the refusal is engendered by "undesirable offer terms and valuation prices". The likelihood of a specific outcome $\mathrm{j}$ is given by:

$$
\mathrm{p}_{\mathrm{it}}^{\mathrm{j}}=\exp \left(\mathrm{X}_{\mathrm{it}}{ }^{\prime} \beta_{\mathrm{j}}\right) /\left[1+\sum_{\mathrm{j}=1}^{3} \exp \left(\mathrm{X}_{\mathrm{it}}{ }^{\prime} \beta_{\mathrm{j}}\right)\right] \text {. }
$$

The vector $\mathrm{X}$ includes the same independent variables used in the previous probit model: $n$. founders, $n$. employees, the dummies born before 2000 and family. Finally, the different proxies of human capital are included (i.e. economic education, technical education and managerial experience 
of firms' founders). The estimates of the multinomial logit model are reported in Table5. Table 6 reports marginal effects.

[Table 5 about here]

[Table 6 about here]

Results indicate that the size of the founding team is positively correlated with the "fear to lose control", while the number of employees seems not to have any significant effect on the motivations of VC refusal. Firms born before 2000 are more likely to refuse VC because of "undesirable offer terms and valuation prices": this result seem to confirm that before the Dot-com Bubble entrepreneurs were more able to obtain higher valuation prices. This trend significantly dropped after 2000. Moreover, the firm familiness is positively related to the motivation "no need of VC". The reluctance of family firms to resort to VC may explain this result: this is in accordance with the fact that family firms prefer internal financing with patient capital and lower cost of capital (McConaughy, 1999; Zellweger, 2007). Capital is typically committed by family members or others revealing the same endowment to the firm as the family itself. However, we also find that family firms are negatively correlated with the motivation of "undesirable offer terms and valuation prices". In this regard, Berrone et al. (2012) affirm that although family firms are reluctant to accept external investors, "poor performance acts as an informational clue that alters the family owners' loss framing" (p. 261). They point out that in extreme situations (i.e., when anticipated poor performance could lead to severe financial hardship to the family's standard of living) the family is forced to reconsider its strategy and this could lead to the acceptance of external sources of funds. In the same vein, Croce and Martì (2016) provide evidence that family firms funded with private equity show lower productivity growth before receiving treatment than other comparable firms. In this situation family firms can be less careful in evaluating the conditions of the contract as they need external capital to survive. This could explain our result that family firms are less likely to resort to the motivation of "undesirable offer terms and valuation prices" in refusing VC.

Founders' economic education is positively correlated with "undesirable offer terms and valuation prices", and negatively with the "no need of VC". This result indicates that a higher founders" economic education favors the comprehension of the relevance of VC financing even though provides the entrepreneur of the instruments to understand whether the terms of the $\mathrm{VC}$ offer are convenient for the firm or not.

Finally, founders' technical education and managerial experience seem not have any significant role in explaining why entrepreneurs refuse VC. 


\section{Impact of VC refusal}

In the last part of our study, we want to analyse the consequences of the venture's choice to refuse VC. Thus, we collected accounting data for both refusing VC and VC-backed firms in the years following their VC offer. We are able to collect information for 104 out of 120 initial firms. Overall, we are able to observe these firms from their foundation year up to the year 2009. Our sample is composed by 841 observations (on average 8.08 years per firm). We then look at firm growth in terms of both sales and total assets and we estimate whether their growth path has been influenced by the choice of refusing VC. We adopt a Gibrat-law testing framework (Evans, 1987) in a panel data setting (Grilli and Murtinu, 2015) and control for different factors influencing firms' growth as: size in the previous period, age (measured in logarithm), years of economic education of founders, years of technical education of founders, familiness and managerial experience.

We resort to a random effects estimation. Results are reported in Table 7.

[Table 7 about here]

We find that the decision to refuse VC has a negative effect on firm growth in terms of both total assets and sales. This seems to confirm the positive role of VC on sustaining venture growth patterns usually found in the previous literature (Colombo and Grilli 2010, Grilli and Murtinu 2014, 2015).

Finally, in order to dig further into this result, we employ a switching regression-type methodology with endogenous switching. ${ }^{5}$ In the first stage, we run a probit model to predict the likelihood of refusing VC and we obtain the inverse Mills ratios for firms refusing VC and VC-backed firms. Among the covariates, we include the ratio between intangible assets and total assets, firm age (in logarithm), the annual VC fundraising in the area in which the focal entrepreneurial firm operates, the average growth level in the two years before, geographical area dummies and industry dummies. In the second stage, we run two separate OLS regressions for firms refusing VC and VC-backed firms, respectively. The dependent variables are represented by growth (in total assets or sales). The covariates include the inverse Mills ratios estimated in the first stage (to account for the endogenous nature of VC refusal based on unobservable factors) and all of the covariates included in the first stage with the exclusion of VC fundraising. The predicted values of firm growth are used to answer the following questions: i) what would the growth of a firm refusing $\mathrm{VC}$ have been had it received VC funding? ii) what would the growth of a VC-backed firm have been had it not received VC funding? Results are reported in Table 8.

[Table 8 about here]

\footnotetext{
${ }^{5}$ This methodology is not new in VC literature (e.g. Croce et al. 2013, Chemmanur et al., 2011; Colombo and Grilli, 2010; Jelic et al., 2005; Lee and Wahal, 2004).
} 
In the first stage firm age and prior average growth have are not significant in predicting VC refusal. $^{6}$ As regards the exclusion restriction, the coefficient of VC fundraising is negative and significant. Conversely, the ratio between intangible assets and total assets, proxy of growth opportunities, is positive and significant, thus suggesting that firms with higher growth opportunity show higher probability to refuse VC. This result is coherent with the theoretical and empirical evidence that shows how contrarily to US, where positive sorting effects between experienced VCs and promising business targets do arise (e.g. Sorensen 2007), in thin VC markets (as the Italian one) this match cannot always be guaranteed. A thin supply-side engenders great bargaining power for VCs in their eventual relationship with possible targets, with the result that a non negligible fraction of promising ventures may find conditions posed by the VC too tight and prefer to decline the offer. In Table 8, we answer the two aforementioned questions and perform the "sliding doors" analysis. In the first part of the Table, results refer to total assets growth. On average, VC-backed firms show a growth $53.5 \%$ higher than what the same firms would have shown had they not received VC funding. A lower and not significant difference in term of sales growth is found for VC-backed firms comparing their sales growth with what the same firms would have shown had they not received VC funding. Similarly, firms refusing VC show a decrease in total assets growth of 6.472 times than what the same firms would have shown had they received VC funding. Similarly, in terms of sales growth, firms refusing VC show a decrease in sales growth of $33.4 \%$ than what the same firms would have shown had they received VC funding. To sum up, we can safely say that our results seem to be confirmed: there is a value-adding effect of VCs on the growth of their portfolio firms. ${ }^{7}$

\section{Conclusions}

Venture capital is often considered as the panacea for all possible financing problems faced by nascent entrepreneurial ventures. Often, these latter are evaluated and judged in the public arena also on the capacity to attract rounds of investment from venture capitalists. The fact that many of all the big companies of today have been VC-backed entrepreneurial ventures of yesterday is a matter of fact. A large body of scientific evidence has also been produced in the recent past testifying the significant positive role that this typology of investment has on a wide spectrum of

\footnotetext{
${ }^{6}$ Results of first stage are not reported in the text of the sake of brevity but are available from the authors upon request.

${ }^{7}$ It is important to highlight that our results are not driven by a selection effect by VC because we only look at firms that received a VC offer, this excluding any screening effect that can allegedly influence our results on the estimation of $\mathrm{VC}$ impact. Moreover, the result about the significance of $\mathrm{VC}$ impact is reinforced by the fact that the growth improvement of VC-backed firms is lower than the absolute value of growth deterioration of firms refusing VC.
} 
venture performances. From this picture, one would expect the entrepreneur receiving a VC offer will go right after to celebrate like she had won the biggest national lottery ever. Reality is (at least to some degree) far from this. Sometimes, entrepreneurs do refuse venture capital. And the phenomenon does not seem to be quite rare. So one wonders: Why do entrepreneurs refuse?

This study aims at shedding light on this issue, which has been totally overlooked by the extant literature. More specifically, for the first time to the best of our knowledge, we provide some temptative answers to this interesting question, by also enquiring which consequences this fundamental choice has produced on firm growth performance and if things could have gone better or worse if entrepreneurial ventures would have chosen differently.

Grounding on the economics and finance literature on venture capital, we search for both possible reasons motivating the $\mathrm{VC}$ refusal decision and possible characteristics of the ventures that may help explaining the phenomenon. We then look at the effects of the $\mathrm{VC}$ refusal choice on the growth performances achieved by the ventures. By using a sample of 120 entrepreneurial ventures which received during their life time at least one $\mathrm{VC}$ offer, with one third refusing it, and through the use of several econometric analyses we found out a series of findings which have several implications.

First, VC-refusing ventures achieved a significantly lower growth performance than the one obtained by the VC-backed firms but also compared to the one hypothetically achievable by their alter ego would have they chosen the "VC door". This result, especially the second part, is more subtle than what it might appear at first glance. Provided that fostering young venture growth embodies a social welfare objective, this finding tells us that a non negligible number of ventures could in principle, and for their characteristics, have the a priori chances to favor and improve social welfare, but they choose not to do it. This is clearly worth of reflections by policy makers. But, what policy makers can do about it?

Our analysis identifies a series of regularities behind the VC refusal behavior, which if from one side help explaining the phenomenon, on the other side may specify the boundaries for some possible policy interventions or give recommendations to entrepreneurs on the relevant features of a nascent team.

First, our results point to venture's ownership structure as an important factor in driving the VC refusal decision. In particular, family ownership positively impacts the choice to refuse VC. Family firms do not refuse VC because they repute offers undesiderable or inconvenient but simply because they do not think to need such financing source (and so probably most of them in our sample received unsolicited offers). But given the hypothetical growth performances they could have achieved in the opposite scenario, they made the wrong choice at least from a social welfare perspective. Thus, our study emphasizes how familiness of nascent entrepreneurial ventures may 
represent an hurdle towards VC financing that policy should aim at addressing. For example by implementing appropriate fiscal policies. In particular, as recognized by many policy-oriented studies in several countries (see for example European Commission 2009) alternative financing sources rather than equity financing, in particular debt financing, are comparatively of greater appeal for many family businesses. Our study corroborates the need from a policy perspective to intervene insofar "[i]n many countries, taxation systems discriminate in favour of debt financing (i.e. corporate tax systems allow the deduction of interest from debt, but do not take into account the cost of capital in the form of equity financing). This 'interest tax shield' encourages debt financing since it lowers the relative cost of debt" (p.14). Taxation regimes should aim at rebalancing things towards equity financing.

Secondly, VC refusal and its underlying motivations are also impacted by the human capital characteristics of the founding teams. Specifically, ventures whose founders have a sufficient level of educational literacy in technical subjects are less eager to refuse VC. While, founding teams with sufficient educational literacy in economics appear more able to gauge eventual benefits of VC financing but also to evaluate the risks and costs of the conditions proposed by VCs. Accordingly, this competence decreases the possibility that they refuse VC because they do not think to need it but at the same time it increases the likelihood to refuse it because they repute $\mathrm{VC}$ posing undesirable offer terms and valuation prices. From one side, this finding highlights the need for founding teams of (high-tech) entrepreneurial ventures where typically technicians have the leadership to be also formed by entrepreneurs with economics educational literacy so to be capable to better assess VC offers. On the other hand, it still reinforces the need from a policy perspective to enlarge the supply spectrum of VCs so to reduce their monopsonistic power towards prospective entrepreneurial ventures targets. This topic is extremely hot because there is an increasing number of public policies implemented at various geographical levels which aim at favoring the development of VC markets/VC supply. Our study confirms the importance of such policies from a different ankle, by showing that the reasons that lead several entrepreneurial ventures to refuse VC financial offers might be strongly interlinked with the small development of VC markets. 
References (to be completed) 


\section{Tables}

Table 1. Distribution of sample firms across industries, geographic areas, and foundation dates

\begin{tabular}{lcccccc}
\hline & \multicolumn{2}{l}{ VC-backed firms } & \multicolumn{2}{l}{ Firms refusing VC } & \multicolumn{2}{c}{ Total } \\
\hline \hline & N. firms & \% & N. firms & \% & N. firms & \% \\
\hline Industry & & & & & & \\
Manufacturing ICT & 15 & $18.75 \%$ & 14 & $35.00 \%$ & 29 & $24.17 \%$ \\
Software \& Internet & 46 & $57.50 \%$ & 18 & $45.00 \%$ & 64 & $53.33 \%$ \\
Other manufacturing & 15 & $18.75 \%$ & 7 & $17.50 \%$ & 22 & $18.33 \%$ \\
Other services & 4 & $5.00 \%$ & 1 & $2.50 \%$ & 5 & $4.17 \%$ \\
Total & $\mathbf{8 0}$ & $\mathbf{1 0 0 \%}$ & $\mathbf{4 0}$ & $\mathbf{1 0 0 \%}$ & $\mathbf{1 2 0}$ & $\mathbf{1 0 0 \%}$ \\
\hline Geographic area & & & & & & \\
Northwest & 36 & $45.00 \%$ & 13 & $32.50 \%$ & 49 & $40.83 \%$ \\
Northeast & 20 & $25.00 \%$ & 17 & $42.50 \%$ & 37 & $30.83 \%$ \\
Centre & 16 & $20.00 \%$ & 6 & $15.00 \%$ & 22 & $18.33 \%$ \\
South $\&$ Isles & 8 & $10.00 \%$ & 4 & $10.00 \%$ & 12 & $10.00 \%$ \\
Total & $\mathbf{8 0}$ & $\mathbf{1 0 0 \%}$ & $\mathbf{4 0}$ & $\mathbf{1 0 0 \%}$ & $\mathbf{1 2 0}$ & $\mathbf{1 0 0 \%}$ \\
\hline Foundation period & & & & & & \\
$1980-1985$ & 6 & $7.50 \%$ & 2 & $5.00 \%$ & 8 & $6.67 \%$ \\
1986-1991 & 15 & $18.75 \%$ & 7 & $17.50 \%$ & 22 & $18.33 \%$ \\
1992-1997 & 18 & $22.50 \%$ & 8 & $20.00 \%$ & 26 & $21.67 \%$ \\
$1998-2003$ & 29 & $36.25 \%$ & 15 & $37.50 \%$ & 44 & $36.67 \%$ \\
$2004-2008$ & 12 & $15.00 \%$ & 8 & $20.00 \%$ & 20 & $16.67 \%$ \\
Total & $\mathbf{8 0}$ & $\mathbf{1 0 0 \%}$ & $\mathbf{4 0}$ & $\mathbf{1 0 0 \%}$ & $\mathbf{1 2 0}$ & $\mathbf{1 0 0 \%}$ \\
\hline
\end{tabular}


Table 2. Descriptive statistics. VC-backed firms and firms refusing VC

\begin{tabular}{lcccc}
\hline & VC-backed firms & Firms refusing VC & $\begin{array}{c}\text { Refusing VC vs VC-backed } \\
\text { firms }\end{array}$ \\
\hline \hline & mean & mean & diff & sign. \\
\hline economic education & 0.288 & 0.200 & -0.088 & \\
technical education & 0.625 & 0.500 & -0.125 & \\
managerial experience & 0.375 & 0.325 & -0.050 & \\
n. employees (logs) & 1.227 & 0.927 & -0.300 & \\
n. founders (logs) & 1.240 & 1.303 & 0.063 & \\
born before 2000 & 0.788 & 0.650 & -0.138 & \\
family & 0.050 & 0.200 & 0.150 & $* * *$ \\
\hline
\end{tabular}


Table 3. Descriptive statistics. Firms refusing VC: motivations

\begin{tabular}{lccc}
\hline & No need of VC & $\begin{array}{c}\text { Fear to lose } \\
\text { control }\end{array}$ & $\begin{array}{c}\text { Undesirable offer } \\
\text { terms and valuation } \\
\text { prices }\end{array}$ \\
\hline \hline & mean & mean & mean \\
\hline economic education & 0.129 & 0.250 & 0.600 \\
technical education & 0.484 & 0.750 & 0.400 \\
managerial experience & 0.323 & 0.500 & 0.200 \\
n. employees (logs) & 0.864 & 1.390 & 0.944 \\
n. founders (logs) & 1.286 & 1.488 & 1.258 \\
born before 2000 & 0.677 & 0.250 & 0.800 \\
family & 0.226 & 0.250 & 0.000 \\
\hline
\end{tabular}


Table 4. Estimate results: probability to refuse VC

\begin{tabular}{|c|c|c|c|c|c|c|c|c|}
\hline & Model I & & Model II & & Model III & & Model IV & \\
\hline \multirow[t]{2}{*}{ n. founders $(\operatorname{logs})$} & 0.2149 & & 0.3643 & & 0.212 & & 0.3613 & \\
\hline & $(0.301)$ & & $(0.319)$ & & $(0.302)$ & & $(0.319)$ & \\
\hline \multirow[t]{2}{*}{ n. employees (logs) } & -0.1473 & & -0.1442 & & -0.1243 & & -0.1313 & \\
\hline & $(0.119)$ & & $(0.121)$ & & $(0.131)$ & & $(0.132)$ & \\
\hline \multirow[t]{2}{*}{ born before 2000} & -0.2741 & & -0.4463 & & -0.2896 & & -0.4522 & \\
\hline & $(0.305)$ & & $(0.307)$ & & $(0.306)$ & & $(0.309)$ & \\
\hline \multirow[t]{2}{*}{ family } & 0.9443 & $* *$ & 0.8772 & $* *$ & 0.9604 & $* *$ & 0.8879 & $* *$ \\
\hline & $(0.417)$ & & $(0.432)$ & & $(0.42)$ & & $(0.435)$ & \\
\hline \multirow[t]{2}{*}{ economic education } & & & -0.3289 & & & & -0.3224 & \\
\hline & & & $(0.295)$ & & & & $(0.295)$ & \\
\hline \multirow[t]{2}{*}{ technical education } & & & -0.5328 & $*$ & & & -0.5293 & $*$ \\
\hline & & & $(0.285)$ & & & & $(0.285)$ & \\
\hline \multirow[t]{2}{*}{ managerial experience } & & & & & -0.1257 & & -0.0709 & \\
\hline & & & & & $(0.295)$ & & $(0.301)$ & \\
\hline \multirow[t]{2}{*}{ Const. } & -0.7242 & & -0.2886 & & -0.7086 & & -0.2845 & \\
\hline & $(0.694)$ & & $(0.73)$ & & $(0.695)$ & & $(0.733)$ & \\
\hline Industry dummies & YES & & YES & & YES & & YES & \\
\hline geographical area dummies & YES & & YES & & YES & & YES & \\
\hline $\mathrm{N}$ & 120 & & 120 & & 120 & & 120 & \\
\hline
\end{tabular}


Table 5. Motivations of VC refusal: multinomial logit estimates

\begin{tabular}{lccc}
\hline & No need of VC & Fear to lose control & $\begin{array}{c}\text { Undesirable offer } \\
\text { terms and valuation } \\
\text { prices }\end{array}$ \\
\hline n. founders (logs) & $1.883(1.067)$ & $5.924 *(6.386)$ & $1.436(3.911)$ \\
n. employees (logs) & $0.747(0.189)$ & $2.109(1.225)$ & $0.69(0.337)$ \\
born before 2000 & $0.493(0.282)$ & $0.061^{* *}(0.075)$ & $10.653^{* *}(12.763)$ \\
family & $5.121^{* *}(4.057)$ & $3.269(5.311)$ & $0.000^{* * *}(0.000)$ \\
economic education & $0.306^{*}(0.193)$ & $0.367(0.453)$ & $8.399^{* * *}(6.622)$ \\
technical education & $0.446(0.228)$ & $0.467(0.757)$ & $0.053(0.11)$ \\
managerial experience & $0.972(0.587)$ & $1.336(1.648)$ & $0.884(1.062)$ \\
const & $0.318(0.409)$ & $0.023(0.112)$ & $0.04(0.183)$ \\
Industry dummies & Yes & Yes & Yes \\
Goegraphical area dummies & Yes & Yes & Yes \\
Obs. & 120 & 120 & 120 \\
Pseudo R & 0.232 & 0.232 & 0.232 \\
Log pseudolikelihood & -79.746 & -79.746 & -79.746 \\
\hline
\end{tabular}

Legend: estimates are derived from multinomial logit regressions with standard errors robust to heteroskedasticity through the HuberWhite method. Relative-risk ratios are reported. In column I, results relate to the likelihood of VC refusal with the motivation of "no need of VC"; column II refers to the likelihood of VC refusal because of "Fear to lose control" motivation. Finally, column III refer to "Offer terms \& Valuation price" motivation of VC refusal. Industry and geographical dummies are included in the estimates (coefficients are omitted in the table). All regressions are estimated with an intercept term. Standard errors in round brackets. $* \mathrm{p}<$ $.10 ; * * \mathrm{p}<.05 ; * * * \mathrm{p}<.01$. 


\section{No need of VC Fear to lose control Undesirable offer terms and} valuation prices

\begin{tabular}{lccc}
\hline \hline n. founders $(\operatorname{logs})$ & $0.100(0.110)$ & $0.047(0.031)$ & $0.008(0.106)$ \\
n. employees $(\operatorname{logs})$ & $-0.058(0.043)$ & $0.027(0.018)$ & $-0.011(0.016)$ \\
born before 2000 & $-0.045(0.111)$ & $-0.200(0.143)$ & $0.018^{* * *}(0.062)$ \\
family & $0.320^{* * *(0.112)}$ & $0.227(0.044)$ & $-0.405^{* *}(0.166)$ \\
economic education & $-0.206^{*}(0.115)$ & $-0.017(0.047)$ & $0.043^{* *}(0.018)$ \\
technical education & $-0.095(0.093)$ & $-0.008(0.065)$ & $-0.135(0.126)$ \\
managerial experience & $-0.006(0.092)$ & $-0.008(0.028)$ & $-0.004(0.037)$ \\
\hline
\end{tabular}




\begin{tabular}{|c|c|c|c|c|}
\hline \multirow[b]{2}{*}{$\mathrm{VC}$ refusal } & \multicolumn{2}{|c|}{ Growth (Total assets) } & \multicolumn{2}{|c|}{ Growth (Sales) } \\
\hline & $\begin{array}{l}-0.1791 \\
(0.092)\end{array}$ & $*$ & $\begin{array}{l}-0.2861 \\
(0.148)\end{array}$ & $*$ \\
\hline $\operatorname{Size}_{\mathrm{t}-1}$ & $\begin{array}{c}-0.0936 \\
(0.041)\end{array}$ & $* *$ & $\begin{array}{c}-0.0798 \\
(0.057)\end{array}$ & \\
\hline age $(\log s)$ & $\begin{array}{l}-0.2179 \\
(0.096)\end{array}$ & $* *$ & $\begin{array}{c}-0.864 \\
(0.187)\end{array}$ & $* * *$ \\
\hline economic education (n. years) & $\begin{array}{l}0.0194 \\
(0.046)\end{array}$ & & $\begin{array}{c}-0.0949 \\
(0.071)\end{array}$ & \\
\hline technical education (n. years) & $\begin{array}{c}0.005 \\
(0.019)\end{array}$ & & $\begin{array}{c}-0.0095 \\
(0.032)\end{array}$ & \\
\hline family & $\begin{array}{c}0.0472 \\
(0.12)\end{array}$ & & $\begin{array}{l}0.0726 \\
(0.176)\end{array}$ & \\
\hline managerial experience & $\begin{array}{l}0.0676 \\
(0.099)\end{array}$ & & $\begin{array}{l}-0.010 \\
(0.174)\end{array}$ & \\
\hline Cons. & $\begin{array}{c}0.9175 \\
(0.23)\end{array}$ & $* * *$ & $\begin{array}{l}2.8645 \\
(0.635) \\
\end{array}$ & $* * *$ \\
\hline N. obs & 841 & & 818 & \\
\hline N. firms & 104 & & 103 & \\
\hline
\end{tabular}


Table 8. Actual and hypothetical growth for VC-backed firms and firms refusing VC.

\section{Total assets growth}

\begin{tabular}{|c|c|c|c|}
\hline & $\begin{array}{l}\text { Actual growth for VC- } \\
\text { backed firms }\end{array}$ & $\begin{array}{l}\text { Growth for VC-backed firms if they had not obtained } \\
\text { VC financing }\end{array}$ & $\begin{array}{c}\text { Growth } \\
\text { variation }\end{array}$ \\
\hline \multirow[t]{2}{*}{ Mean } & 0.188 & -0.336 & $-0.525 * * *$ \\
\hline & $\begin{array}{l}\text { Actual growth for firms } \\
\text { refusing VC }\end{array}$ & $\begin{array}{l}\text { Growth for firms refusing VC if they had obtained } \\
\text { VC financing }\end{array}$ & $\begin{array}{c}\text { Growth } \\
\text { variation }\end{array}$ \\
\hline \multirow[t]{3}{*}{ Mean } & 0.106 & 6.578 & $6.472 * * *$ \\
\hline & & Sales growth & \\
\hline & $\begin{array}{l}\text { Actual growth for VC- } \\
\text { backed firms }\end{array}$ & $\begin{array}{l}\text { Growth for VC-backed firms if they had not obtained } \\
\text { VC financing }\end{array}$ & $\begin{array}{c}\text { Growth } \\
\text { variation }\end{array}$ \\
\hline \multirow[t]{2}{*}{ Mean } & 0.228 & 0.232 & 0.004 \\
\hline & $\begin{array}{l}\text { Actual growth for firms } \\
\text { refusing VC }\end{array}$ & $\begin{array}{l}\text { Growth for firms refusing VC if they had obtained } \\
\text { VC financing }\end{array}$ & $\begin{array}{c}\text { Growth } \\
\text { variation }\end{array}$ \\
\hline Mean & 0.098 & 0.432 & $0.334 * * *$ \\
\hline
\end{tabular}

